\title{
Normotensive, Normokalemic Hyperaldosteronemia of a Grown-up Woman Diagnosed as Salt-Losing 21-Hydroxylase Deficiency in Neonatal Period
}

\author{
Toshihide Yamamoto* \\ Yao Tokushukai General Hospital, Yao, Japan
}

*Corresponding author: Toshihide Yamamoto, Yao Tokushukai General Hospital, Yao, Japan, Tel: 8172-9-93-8500; E-mail: ysin@osk4.3web.ne.jp

Received: 12 Feb, 2019 | Accepted: 25 Feb, 2019 | Published: 28 Feb, 2019

Citation: Yamamoto T (2019) Normotensive, Normokalemic Hyperaldosteronemia of a Grown-up Woman Diagnosed as Salt-Losing 21-Hydroxylase Deficiency in Neonatal Period. Int J Endocrinol Metab Disord 5(1): dx.doi.org/10.16966/2380-548X.153

Copyright: (c) 2019 Yamamoto T. This is an open-access article distributed under the terms of the Creative Commons Attribution License, which permits unrestricted use, distribution, and reproduction in any medium, provided the original author and source are credited.

\begin{abstract}
A woman in her mid-30's with salt-losing 21-hydroxylase deficiency diagnosed in neonatal period had been supplemented gluco- and mineralocorticoids before she quit the regimen because of steroid-induced obesity. After quitting, she was referred to the author. Review of endocrine records in preceding two years revealed hyper-reninemic hyperaldosteronism without hypertension and hypokalemia. Because of stubborn refusal to continue the supplementation of gluco- and mineralo-corticoids, she was allowed to be off the supplementation for two months after possible consequences were explained. When she returned two months later, she was normotensive and normokalemic in the face of hyperaldosteronemia. Since then up to the present, she has been free of gluco- and mineralo-corticoids on days not portend physical or psychosocial stress. She has maintained normotension and normokalemia. Overproduction of progesterone and $17 \alpha$-hydroxyprogesterone, known to have anti-aldosterone activity, appears responsible for hyper-aldosteronemia and apparent aldosterone refractoriness of this patient.
\end{abstract}

Keywords: 21-hydroxylase deficiency; Aldosterone; Cortisol; Progesterone; 17-hydroxyprogesterone

\section{Background}

Almost three decades have elapsed since congenital adrenal hyperplasia was included in neonatal screening program in Japan. Many patients with this disorder supposedly have reached adulthood. Problems related to care transfer from pediatric endocrinologists were recently reviewed by Auchus RJ, et al. [1], who wrote the goal of mineralocorticoid replacement [for grownup patients with salt-losing 21-hydroxylase deficiency (21-OHD)] is to maintain plasma renin activity as low as possible without causing hypertension, hypokalemia, orthostatic hypotension, or salt craving [sic]. As for mineralocorticoid supplementation in adult patients with 21-OHD, the panel of the recent diagnostic and management guideline of The Endocrine Society write as follows: the optimal dose of Fludrocortisones (FC) supplementation in adult patients with 21-OHD has not been critically studied; most non-hypertensive adults with 21-OHD benefit from continued mineralocorticoid treatment; maintenance treatment of FC of 0.05 to $0.2 \mathrm{mg}$ per day is suggested [2]

\section{Case Presentation}

The patient with 21-hydroxylase deficiency (vide infra) was 34 years old when her endocrine care was asked by a pediatric endocrinologist of her childhood. He had treated the patient with varying doses of Hydrocortisone (HC) and FC until her care was transferred to an endocrinologist at the age of 32 years. Then, she had been supplemented with varying doses of Dexamethasone and FC in subsequent two-year period (vide infra) before she quit his care because of being intolerant of steroid-associated obesity. She returned to the pediatric endocrinologist, who asked the author to take over her care. At the time of the transfer to the author, the patient brought in two sets of documents, i.e., narrative summary of an endocrine history of 32 years from her neonatal period by the pediatric endocrinologist and data sheets of subsequent two years under the second endocrinologist's care.

In the first document, following items were depicted: she was born with a weight of 2,420 grams with ambiguous genitalia; her serum sodium concentration was $121,125 \mathrm{mEq} / \mathrm{L}$ and potassium $5.4 \sim 8.0$ $\mathrm{meq} / \mathrm{L}$ two weeks after birth; a gas chromatographic study of urinary steroids was reportedly consistent with 21-hydroxylase deficiency. In the second document, data of blood tests related to corticosteroids and corticosteroid supplementation had been recorded in a chronological order. The author re-arranged these data in reference to corticosteroid regimens in five periods 1 through 5 (Table 1). From table 1 it was learned that ACTH level was brought in the recommended range of the guideline of 21-OHD management [1] in Period 5 where in regimen of dexamethasone $0.875 \mathrm{mg} /$ day without $\mathrm{FC}$ was employed. Normokalemia had been maintained in the presence of high plasma renin activities and normal or high aldosterone levels by supplementation with either 0.025 or $0.05 \mu \mathrm{g}$ of FC per day in Periods 
Table 1: Selected Electrolyte and Endocrine Data in Five Periods Treated with Varying Combination of Hydrocortisone, Dexamethazone, and Fludrocortisone.

\begin{tabular}{|c|c|c|c|c|c|c|}
\hline & Period 1 & Period 2 & Period 3 & Period 4 & Period 5 & \\
\hline & $\left(\sim 09 / 7^{*}\right)$ & $(09 / 8 \sim 10 / 5)$ & $(10 / 6 \sim 10 / 10)$ & $(10 / 10 \sim 11 / 1)$ & $(11 / 2 \sim 11 / 7)$ & Reference ranges** \\
\hline \multicolumn{7}{|c|}{ Doses of corticosteroids (mg/day) } \\
\hline Hydrocortisone & 20 & & & & & \\
\hline Dexamethazone & & 0.835 & 0.9 & 0.9 & 0.875 & \\
\hline Fludrocortisone & 0.05 & 0.05 & 0.05 & 0.025 & 0.025 & \\
\hline АCTH (pg/ml) & 475 & 114 & 33.9 & 16.3 & 7.9 & $7.2-63.3$ \\
\hline Cortisol ( $\mu \mathrm{g} / \mathrm{dl})$ & 2 & 1.6 & 1 & 1 & 1.2 & $4.5-21.1$ \\
\hline 17-OH progesterone (ng/ml) & 310 & 320 & 17 & n.m. & n.m. & $0.2-4.5$ \\
\hline Plasma renin activity $(\mathrm{ng} / \mathrm{ml} / \mathrm{h})$ & 1.2 & 6.4 & 2.4 & 2.7 & 5 & $0.3-4.0$ \\
\hline Aldosterone (ng/dl) & 19.2 & 41.8 & 10.8 & 13.8 & 23.9 & $3.0-15.9$ \\
\hline Aldosterone/renin ratiot & 16.0 & 6.5 & 4.5 & 5.1 & 4.8 & \\
\hline Serum potassium (mEq/L) & 3.9 & 4.2 & 4.0 & 4.6 & 4.4 & \\
\hline
\end{tabular}

Blood samples were drawn after the subject being kept in supine position for 30 minutes.

*Arabic figures of periods 1 through 5, e.g, 09/7 designates July, 2009.

** provided by B.M.L., Saitama, Japan,,$+ \mathrm{ng} / \mathrm{dl}$ divied by $\mathrm{ng} / \mathrm{ml} / \mathrm{h}$.

Abbreviation: not measured for cancellation of the release of 17-OH progesteron assay kit (September, 2010).

1 through 4. 17a-hydroxyprogesterone (17-OHP) levels had remained elevated in these periods. She had had menstruation in these periods.

When seen by the author first time, her height was $151 \mathrm{~cm}$, weight $75.5 \mathrm{~kg}$, body mass index $33.1 \mathrm{~kg} / \mathrm{m}^{2}$. She had been normotensive and amenorrheic after discontinuing the supplementation of corticosteroid. She initially agreed to the author's proposal to keep supplementation consisting of HC $15 \mathrm{mg}$ in three unequally divided doses and FC $0.05 \mathrm{mg}$ per day. Nevertheless, she soon quit taking both apparently without overt ill effects. Her weight reduced to $70 \mathrm{~kg}$. After being explained about possible consequences of withholding $\mathrm{HC}$ and FC, she opted staying being off $\mathrm{HC}$ and $\mathrm{FC}$ for subsequent two months. She was advised to keep salt intake sufficiently and to take HC 10 to $20 \mathrm{mg} /$ day on days when she foresees physical or psychosocial stress. This trial was in part aimed to convince her of the importance of continuing the supplementation.

When she returned to the clinic two months later, her weight reduced to $64 \mathrm{~kg}$ (BMI $28.1 \mathrm{~kg} / \mathrm{m}^{2}$ ) and her blood pressure was ranging from 120-130/70-80 mmHg. Serum electrolytes, creatinine, and hormones related to pituitary-adrenal axis of this period (period 6) were shown in table 2: the serum sodium and potassium were in the normal ranges; ACTH level was elevated; serum cortisol level was subnormal and urinary excretion of cortisol was borderline low; both serum and urinary excretion of aldosterone were elevated.

Since then, she has been kept off corticosteroid supplementation. Repeated studies of chemistry and hormone of blood and urine revealed results similar to those of the first study (Table 2, Period 7). The results of another study done two years later were also similar and the progesterone level, $36.9 \mathrm{ng} / \mathrm{ml}$, was in the ranges of pregnant women (Table 2, Period 8, progesterone measured instead of 17-OHP because of the manufacturer's cancellation of the release of 17-OHP assay kit in September, 2008). She has had no menstrual periods while not being supplemented with glucocorticoid. Up to the present, she has been allowed to be free of corticosteroid supplementation, instructed to have sufficient salt intake, and advised to take 10 to $20 \mathrm{mg} \mathrm{HC}$ only on days when she foresees physical or psychosocial stress.
Studies of chemistry and hormone of blood and urine were repeated twice (Table 2, Periods 8 and 9). The results of electrolytes and creatinine of this period were similar to those of other periods. An arterial gas analysis revealed $\mathrm{pH} 7.40, \mathrm{pO}_{2} 93 \mathrm{mmHg}, \mathrm{pCO}_{2} 35.6$ $\mathrm{mmHg}$, and bicarbonate $21.7 \mathrm{mmol} / \mathrm{l}$. (obtained between period 6 and period 7). In this period, urine was acidic and urine showed positive anion gap (Table 2), an indirect measure of ammonium ion in urine [3].

The measurements of ACTH, plasma rennin activity, plasma aldosterone concentration, urinary concentrations of cortisol and aldosterone were performed by Biomedical Laboratory (BML, Saitama, Japan).

\section{Discussion}

Although the account of her neonatal period is suggestive of salt wasting 21-OHD, her current phenotype appears consistent with of simple virilizing 21-OHD. The gene analysis of CYP21A2 has not been done.

In this patient, cortisol levels and urinary excretion of cortisol of this patient were in low-normal range in periods 6 and 7 (Table 2). Her cortisol production has apparently ameliorated modestly by overproduction of ACTH over many years. As the secretory rate of aldosterone is three-order magnitude less than that of cortisol, i.e. 1.5$12.5 \mu \mathrm{g} /$ day (excretion rate, without salt restriction) [4] vis. $9.9 \pm 2.7$ $\mathrm{mg} /$ day (production rate) [5], the recovery of aldosterone production could be understood. Another explanation of aldosterone production in patients with 21-OHD is provided by Gomes and coworkers [6], i.e. aldosterone is synthesized from 21-hydroxylation of progesterone (not from 17-OHO) by hepatic enzymes, CYP2C19 and CYP3A4, though less efficiently than CYP21A, in five children with 21-OHD.

Despite hyperaldosteronemia and hyperaldosteronuria, she had neither hypertension nor hypokalemia. Serum aldosterone levels and urinary excretion of aldosterone were more than the reference values in recent years (Table 2). An arterial gas analysis revealed 
Table 2: Blood Pressure, Biochemical and Endocrine Data of Blood and Urine of a Grown-up Woman with 21-hydroxylase Deficiency (salt-losing tye in neonatal period) while Gluco- and Mineralo-corticoids being with held.

\begin{tabular}{|c|c|c|c|c|c|c|}
\hline & & Period 6 & Period 7 & Period 8 & Period 9 & \\
\hline Period & & February, 14 & November, 15 & February-March, 16 & September, 18 & $\begin{array}{l}\text { Reference } \\
\text { ranges* }\end{array}$ \\
\hline $\begin{array}{l}\text { Blood pressure, } \\
\text { Systolic/diastolic ( } \mathrm{mmHg} \text { ) }\end{array}$ & & $120 / 90$ & $95 / 60$ & $90 / 70$ & $100 / 80$ & \\
\hline \multirow[t]{5}{*}{ Serum } & $\mathrm{Na}(\mathrm{mEq} / \mathrm{I})$ & 141 & 140 & 140 & & \\
\hline & $\mathrm{K}(\mathrm{mEq} / \mathrm{l})$ & 4.8 & 5.2 & 5.1 & & \\
\hline & $\mathrm{Cl}(\mathrm{mEq} / \mathrm{l})$ & 104 & 104 & 105 & & \\
\hline & creatinine (mg/dl) & 0.63 & 0.77 & 0.79 & & \\
\hline & osmolality (Osm/kg) & & & 288 & & \\
\hline \multirow[t]{7}{*}{ 24-hour urine } & $\mathrm{pH}$ & 6.0 & 5.5 & $5.5^{\dagger}$ & & \\
\hline & volume (ml/day) & 3210 & 2350 & -- & & \\
\hline & $\mathrm{Na}(\mathrm{mEq} / \mathrm{l})$ & 50 & 118 & $176^{\dagger}$ & & \\
\hline & $\mathrm{K}(\mathrm{mEq} / \mathrm{l})$ & 15 & 14 & $47+$ & & \\
\hline & $\mathrm{Cl}(\mathrm{mEq} / \mathrm{l})$ & 44 & 112 & $197+$ & & \\
\hline & creatinine $(\mathrm{mg} / \mathrm{dl})$ & 21 & 51 & $89+$ & & \\
\hline & anion gap (mEq/L) & 21 & 20 & $26+$ & & \\
\hline \multirow[t]{6}{*}{ Blood (obtained in morning) } & ACTH $(\mathrm{pg} / \mathrm{ml})$ & 42.7 & 118 & 643 & 193 & $7.2-63.3$ \\
\hline & cortisol $(\mu \mathrm{g} / \mathrm{dl})$ & 2.2 & 6.7 & 10.6 & 5.1 & $4.5-21.1$ \\
\hline & plasma renin activity $(\mathrm{ng} / \mathrm{ml} / \mathrm{h})$ & 3.3 & 6.2 & & 12.9 & $0.2-3.9$ \\
\hline & aldosterone (ng/ml) & 32.5 & 64.4 & & 106 & $3.6-24.0$ \\
\hline & aldosterone/renin ratioł & 9.8 & 10.4 & & 8.2 & \\
\hline & progesterone (ng/ml) & & & 36.9 & 35.8 & $\begin{array}{l}23.9- \\
141.49\end{array}$ \\
\hline \multirow[t]{2}{*}{ 24-hour urine } & cortisol ( $\mu \mathrm{g} /$ day) & 28.6 & 89.3 & & & $26-187$ \\
\hline & aldosterone ( $\mu \mathrm{g} / \mathrm{day})$ & 61 & 28.2 & & & $<7.5$ \\
\hline
\end{tabular}

*-Provided by B.M.L, Saitama, Japan. Reference range for pregnant women in the first trimester.

$\dagger$-data of spot urine; $\ddagger$, aldosterone $(\mathrm{ng} / \mathrm{dl}) /$ divided by renin activity $(\mathrm{ng} / \mathrm{ml} / \mathrm{h}$ ).

compensated mild metabolic acidosis. Acidic urine and positive urine anion gap were against distal renal tubular acidosis. Hence, hyperaldosteronism reportedly associated with distal renal tubular acidosis [7] is unlikely responsible in this patient. During pregnancy, elevated plasma renin activity $[8,9]$ and increase in plasma levels of progesterone and aldosterone $[10,11]$ have been known. The patient's plasma renin activity and levels of aldosterone and progesterone were elevated to the similar magnitude as those described in the literature [11]. Antagonistic activity of progesterone and 17-OHP against aldosterone receptor is shown in COS-7 cells, a cell line derived from African green monkey kidney, transfected with human mineralocorticoid receptor DNA [12]. Development of hypertension and hypokalemia appears to be prevented by overproduction of 17-OHP and progesterone.

Development of adrenal adenoma manifested by Cushing syndrome was reported in a young woman with late onset of 21-OHD, who had been treated as polycystic ovary syndrome without supplementation of gluco- and mineralo-corticoid [13]. If serum cortisol and aldosterone levels of this patient further increase, the image study of the adrenals would be necessary. The long-term outcome of persistent amenorrhea conceivably attributable to unsuppressed progesterone production needs to be clarified.

Though she has been not supplemented with gluco- and mineralocorticoid unless she foresees physical or psychosocial stress, she is provided with several days' supply of hydrocortisone in case of need and instructed to carry medical alert card depicting the diagnosis as well as treatment at acute care facilities.

\section{Conclusion}

An adult woman with salt-losing 21-OHD diagnosed in neonatal period remained normotension and normokalemia without gluco- and mineralo-corticoid supplementation in the face of hyper-reninenia and hyperaldosteronemia suggestive of aldosterone resistance presumably resulting from unsuppressed progesterone secretion. Long-acting glucocorticoid of a dose sufficient to suppress secretion of ACTH, progesterone and 17-OHP could partially ameliorate renin and aldosterone secretion in a tradeoff of intact menstruation and steroid-induced obesity. Optimal treatment of 21-OHD of grownup remains to be a difficult issue.

\section{Declaration of Interest and Funding}

The author declares that there is no conflict of interest. The author is the patient's current attending endocrinologist. Dr. Takuma Kondo referred the patient and provided endocrine data since neonatal period. Endocrine data in two-year period prior to the patient's first clinic visit were collected by Dr. Hiroyuki Koshiyama. Both of them granted use of their data in this paper. This research did not receive any specific grant from any funding agency of commercial or non-forprofit sector. 


\section{Patient's Consent}

The patient has submitted written informed consent to publish this observation after reading translated version of the manuscript.

\section{References}

1. Auchus RJ, Arlt W (2013) Approach to the patient: the adult with congenital adrenal hyperplasia. J Clin Endocrinol Metab 98: 26452655.

2. Speiser PW, Arlt W, Auchus RJ, Baskin LS, Conway GS, et al. (2018) Congenital adrenal hyperplasia due to steroid 21-hydroxylase deficiency: An endocrine society clinical practice guideline. J Clin Endocrinol Metab 103: 4043-4088.

3. Kim GH, Han JS, Kim YS, Joo KW, Kim S, et al. (1996) Evaluation of urine acidification by urine anion gap and urine osmolal gap in chronic metabolic acidosis. Am J Kidney Dis 27: 42-47.

4. Sealey JE, Bühler FR, Laraugh JH, Manning EL, Brunner HR (1972) Aldosterone excretion. Physiological variations in man measured by radioimmunoassay or double-isotope dilution. Circ Res 31: 367-378.

5. Esteban NV, Loughlin T, Yergery AL, Zawadzji JK, Booth JD, et al. (1991) Daily cortisol production rate in man determined by stable isotope dilution/mass spectrometry. J Clin Endocrinol Metab 72: 3945.

6. Gomes LG, Huang N, Agrawal V, Mendonça BB, Bachega TA, et al. (2009) Extraadrenal 21-hydroxylation by CYP2C19 and CYP3A4: effect on 21-hydroxylase deficiency. J Clin Endocrinol Metab 94: 89-95.
7. Sebastian A, McSherry E, Morris RC Jr. (1971) Renal potassium wasting in renal tubular acidosis (RTA): its occurrence in type 1 and 2 RTA despite sustained correction of systemic acidosis. J Clin Invest 50: 667-678.

8. Weinberger MH, Kramer NJ, Petersen LP, Cleary RE, Young PC (1976) Sequential changes in the rennin-angiotensin-aldosterone systems and plasma progesterone concentration in normal and abnormal human pregnancy. Perspect Nephrol Hypertens 5: 263-269.

9. Lammintausta R, Erkkola R (1977) Renin-angiotensin-aldosterone system and sodium in normal pregnancy: a longitudinal study. Acta Obstet Gynecol Scand 56: 221-225.

10. Ledoux F, Genest J, Nowaczynski W, Kuchel O, Lebel M (1975) Plasma progesterone and aldosterone in pregnancy. Can Med Assoc J 112: 943-947.

11. Dörr HG, Heller A, Versmold HT, Sippell WG, Hermann $M$, et al. (1989) Longitudinal study of progestins, mineralocorticoids, and glucocorticoids throughout human pregnancy. J Clin Endocrinol Metab 68: 863-868.

12. Mooij CF, Parajes S, Pijnenburg-Kleizen KJ, Arlt W, Krone N, et al. (2015) Influence of 17-hydroxyprogesterone, progesterone and sex steroids on mineralocorticoid receptor transactivation in congenital adrenal hyperplasia. Horm Res Paediatr 83: 414-421.

13. Endogan G, Pabuccu R, Ertek S, Israel S, Yilmaz B, et al. (2014) Lateonset congenital adrenal hyperplasia with Cushing syndrome. Intern Med 53: 1955-1959. 